\title{
PERAN BRAND IMAGE MEMEDIASI PENGARUH KREDIBILITAS CELEBRITY ENDORSER TERHADAP NIAT BELI
}

\author{
Nyoman Yasinta Windyastari ${ }^{1}$ \\ Eka Sulistyawati ${ }^{2}$ \\ ${ }^{1,2}$ Fakultas Ekonomi dan Bisnis Universitas Udayana (Unud), Bali, Indonesia \\ E-mail:_yasintawindyastari@gmail.com
}

\begin{abstract}
ABSTRAK
Semakin pesat dan ketatnya persaingan bisnis yang dibarengi dengan semakin selektifnya konsumen dalam pemilihan kosmetika untuk digunakan, menyebabkan adanya tuntutan perusahaan dalam pemberian informasi dan image yang positif sehingga dapat menarik pelanggan potensial. Penelitian ini bertujuan untuk menguji pengaruh kredibilitas celebrity endorser terhadap niat beli melalui brand image produk kosmetik wardah di Kota Denpasar. Penelitian ini dilakukan di Kota Denpasar dengan melibatkan 100 orang responden dengan metode purposive sampling. Data dikumpulkan melalui penyebaran kuesioner. Teknik analisis data yang digunakan adalah teknik analisis jalur (path analysis) dan uji sobel. Hasil penelitian menemukan bahwa kredibilitas celebrity endorser berpengaruh positif dan signifikan terhadap brand image. Brand image berpengaruh positif dan signifikan terhadap niat beli. Kredibilitas celebrity endorser berpengaruh positif dan signifikan terhadap niat beli. Brand image memediasi pengaruh kredibilitas celebrity endorser terhadap niat beli kosmetik wardah di Kota Denpasar.
\end{abstract}

Kata kunci: kredibilitas celebrity endorser, brand image, niat beli.

\begin{abstract}
The more rapid and intense business competition coupled with the increasingly selective of consumers in the selection of cosmetics to use, causing the company's demands in providing information and a positive image that can attract potential customers. This study aims to examine the effect of credibility of celebrity endorser to purchase intention through brand image of wardah cosmetic product in Denpasar City. This research was conducted in Denpasar City involving 100 respondents with purposive sampling method. Data were collected through questionnaires. Data analysis technique used is path analysis technique and sobel test. The result of research shows that credibility of celebrity endorser has positive and significant effect to brand image. Brand image has a positive and significant effect on purchase intention. The credibility of celebrity endorser has a positive and significant effect on purchase intention. Brand image mediates the influence of celebrity endorser's credibility to the purchase intention of wardah cosmetics in Denpasar City.
\end{abstract}

Keywords: credibility of celebrity endorser, brand image, purchase intention. 


\section{PENDAHULUAN}

Berkembangnya kemajuan teknologi yang sangat pesat membuat persaingan bisnis pada dunia usaha semakin ketat. Dimana berkembangnya teknologi memudahkan konsumen dalam mendapatkan informasi secara cepat melalui media. Dengan semakin ketatnya kemajuan ilmu pengetahuan dan teknologi ini perusahaan dituntut tanggap dengan keinginan konsumen dengan memberikan informasi dan membuat strategi bisnis dalam memperkenalkan produknya agar mudah diterima dan di konsumsi oleh konsumen.

Produk kosmetika tidak hanya wanita yang menggunakan kosmetik tetapi ada beberapa pria juga menggunakanya sebagai perawatan diri. Data yang diterbitkan oleh Persatuan Perusahaan Kosmetika Indonesia (Perkosmi) memperkirakan tahun ini penjualan kosmetik dapat tumbuh hingga Rp 11,2 triliun, naik 15\% dibandingkan proyeksi 2012 sebesar Rp 9,76 triliun. Dari sisi ekspor, industri kosmetik ditaksir tumbuh 20\% menjadi US\$ 406 juta (kemenperin.go.id). Persaingan bisnis produk kosmetika sangatlah ketat. Banyaknya kosmestik impor yang berlomba - lomba menyaingi komsetik dalam negeri, hal tersebut ditunjukan dengan data dari Kementerian Perindustrian yang menyatakan pertumbuhan kosmetik lokal Indonesia kalah besar jika dibandingkan dengan kosmetik impor dan kosmetik brand multinasional dengan penjualan kosmetik impor yang naik 30 persen itu termasuk dua kali lipat dari penjualan kosmetik Indonesia (kemenperin.go.id).

Kemunculan brand kosmetik luar tidak mengurangi keinginan perusahaan kosmetik lokal dalam memasarkan produknya. Menurut Wiyantari dan Raka 
(2016) menyatakan bahwa masih tingginya minat konsumen pada kosmetik dalam negeri yang diminati oleh kalangan menengah yang menjadi pemicu pesatnya penjualan kosmetik dalam negeri dan salah satu produk yang sedang menggarap pasar saat ini adalah Wardah. Wardah kosmetik bernaungan dibawah PT. Paragon Technology Innovation (PTI) berdiri sejak 1985 dan telah mendapatkan sertifikat Halal dari LPPOM MUI dengan kapasitas produksi yang besar dan formulasi kosmetik yang unggul (pti-cosmetics.com). Wardah kosmetik mempunyai berbagai macam produk yang dikeluarkannya sehingga konsumen dapat memilih produk sesuai kebutuhan dengan harga yang sangat terjangkau.

Berdasarkan dari fenomena di atas dapat dikatakan bahwa penjualan kosmetika dikatakan tumbuh sangat pesat yang menandakan adanya perilaku niat beli produk kosmetik yang tinggi di masyarakat Indonesia. Tantangan lain yang dihadapi oleh perusahaan adalah saat ini dimana konsumen lebih teliti dan selektif dalam memilih produk yang digunakan (Prayuana dan Andjarwati,2013). Dengan demikian perusahaan dituntut harus membuat strategi pemasaran untuk menarik konsumen yang akan menimbulkan niat beli dengan strategi tersebut dengan berbagai cara salah satunya dengan pemberian informasi tentang produk untuk menarik perhatian dan menciptakan asosiasi positif (Pangastuti dan Purnami, 2015). 
Tabel 1.

Katagori Kosmetik Survei TOP BRAND 2015-2017

\begin{tabular}{ccccccc}
\hline Rank & \multicolumn{2}{c}{$\mathbf{2 0 1 5}$} & \multicolumn{2}{c}{$\mathbf{2 0 1 6}$} & \multicolumn{2}{c}{$\mathbf{2 0 1 7}$} \\
\hline 1 & Wardah & $13.9 \%$ & Viva & $15.5 \%$ & Wardah & $17.0 \%$ \\
2 & Viva & $12.3 \%$ & Wardah & $15.5 \%$ & Viva & $16.0 \%$ \\
3 & Sariayu & $10.4 \%$ & Marcks & $12.1 \%$ & Marcks & $11.8 \%$ \\
4 & Marcks & $7.9 \%$ & Sariayu & $8.3 \%$ & Sariayu & $8.0 \%$ \\
5 & La Tulipe & $7.1 \%$ & Pixy & $6.8 \%$ & Pixy & $6.7 \%$ \\
6 & Pigeon & $5.2 \%$ & La Tulipe & $4.4 \%$ & La Tulipe & $4.2 \%$ \\
\hline
\end{tabular}

Tabel 1 menunjukkan TOP BRAND kosmetik tahun 2015-2017 dimana tahun 2015 wardah berada pada tingkat pertama sebesar $13.9 \%$ sedangkan di tahun 2016 wardah mengalami penurunan di peringkat kedua yaitu sebesar $15.5 \%$.

Strategi komunikasi dengan menggunakan dukungan selebriti dalam mempromosikan suatu produk, nantinya akan berdampak juga pada brand image produk itu sendiri (Sabunwala, 2013). Celebrity endorser adalah orang yang sebagian besar dikenal oleh masyarakat luas dan memanfaatkan identifikasi tersebut untuk mendukung produk dalam iklan (McCracken, 1989 dalam Roy et al. 2013). Shafiq et al. (2011) menyatakan bahwa celebrity endoser merupakan sosok orang yang menarik, mampu mengiklankan produk, dan memiliki kredibilitas yang baik, sehingga daat menumbuhkan niat beli pada orang yang melihat iklan dan untuk membeli produk yang diiklankan. Pradhan et al. (2014) menyatakan bahwa dukungan celebrity endorser membantu konsumen untuk lebih berhubungan dengan selebriti dan dapat membantu dalam mengembangkan sikap positif terhadap merek untuk meningkatkan minat beli konsumen. Bagi perusahaan celebrity endorser mempunyai peran yang sangat penting dalam mengiklankan suatu produk yang dapat meningkatkan dan menurukankan nilai dari suatu produk yang dipasarkan dan niat beli konsumen dapat meningkat 
apabila konsumen mendapatkan manfaat lebih dari apa yang konsumen bayar untuk sebuah produk (Hansudoh, 2012). Brand image yang baik akan menimbulkan nilai-nilai emosional konsumen, oleh sebab itu perusahaan perlu untuk meningkatkan brand image mereka karena nilai emosional ini akan memicu terjadinya persepsi yang positif akan suatu produk yang akan menimbulkan niat beli (Weli dan Rahyuda, 2016).

Produk wardah kosmetik menjadi top brand sebagai merek lokal yang banyak dari beberapa produk diminati oleh konsumen. Produknya sudah diakui dan halal oleh majelis ulama indonesia menjadi suatu ketertarikan konsumen yang muslimah untuk menggunakan produk kosmetik Wardah tersebut. Wardah menggunakan celebrity endorser yang dalam kesehariannya memakai hijab, hal ini diharapkan dapat memperkuat kesan produk dalam benak konsumen mengenai pesan atau informasi yang akan disampaikan. Semakin baik kredibilitas, daya tarik, keahlian, kepercayaan diri seseorang celebrity maka semakin baik juga pengaruhnya terhadap brand image suatu produk yang nantinya akan berdampak pada pemilihan produk tersebut oleh konsumen (Putra dan Sulistyawati, 2015).

Para artis berwajah cantik dan berhijab dipilih sebagai model kosmetik berlabel halal ini yaitu Ineke Koesherawati terpilih sebagai brand ambassador pada tahun 2002. Awal tahun 2016 Wardah mengangkat Natasha Rizky, Ria Miranda, Dian Pelangi, Zaskia Sungkar, Dewi Sandra, Lisa Namuri, Tatjana Saphira yang memiliki karakteristik di setiap diri mereka sendiri dalam penyampaian informasi untuk menarik konsumen dalam menggunakan kosmetik Wardah (tribunnews.com). Maka dari itu kredibilitas celebrity endorser perlu 
diperhatikan sehingga dapat membangun citra diri di konsumen yang akan menimbulkan minat beli konsumen.

Prasurvei pendahuluan yang dilakukan pada 10 responden menyatakan 50\% memiliki niat untuk membeli produk kosmetik wardah, sedangkan sisanya 50\% menyatakan tidak memiliki niat membeli kosmetik wardah dikarenakan lebih tertarik menggunakan kosmetik merek lain.

Pada penelitian sebelumnya, Penelitian Maulana dalam Amanda (2014) menyatakan bahwa terdapat pengaruh antara kredibilitas celebrity endorser dengan brand image yang lebih efektif menghasilkan respon yang positif terhadap brand image dan meningkatkan keinginan untuk membeli. Hasil penelitian Rini dan Astuti (2012), Nisa dan Amal (2013) serta Sari dan Djatikusuma (2013) kredibilitas seorang celebrity endorser berpengaruh signifikan dan positif terhadap brand image karena penggunaan celebrity endorser yang tepat dapat meningkatkan brand image suatu produk atau layanan dan dapat meningkatkan niat beli.

Rahma dalam Kurniawan (2012) mengemukakan bahwa brand image akan berpengaruh langsung terhadap tingginya minat beli terhadap suatu produk karena konsumen akan memiliki alasan untuk membeli atau menggunakan produk dengan brand image yang dianggap khalayak sebagai produk yang baik, berkualitas, dan dipakai oleh orang terkenal. Menurut penelitian dari Bhakar et al. (2013) bahwa brand image merupakan anteseden purchase. Ruslim dan Andrew (2012), Jalilvand dan Samei (2012), Wahyuni dan Suparna (2014), Wang 
dan Tsai (2014), serta Subiyanto (2013) didapatkan hasil bahwa terdapat pengaruh yang positif dan signifikan antara brand image dan purchase intention.

Hansudoh (2012) menyebutkan dalam penelitiannya bahwa kredibilitas celebrity endorser berpengaruh positif dan signifikan terhadap purchase intention. Sallam (2011) menunjukkan hasil yang sama bahwa kredibilitas celebrity endorser memiliki pengaruh yang positif pada niat beli konsumen di Arab Saudi. Hasil penelitian yang sama juga mendapatkan hasil yang sama dengan penelitian diatas antara lain: Indraswari dan Pramudana (2014), Apejoye (2013), Khan (2013) dan Zafar (2012). Beberapa penelitian menunjukan hasil bertentangan. Penelitian yang dilakukan oleh Stephie dkk. (2013) yang mendapatkan hasil kredibilitas celebrity endorser tidak berpengaruh signifikan terhadap nilat beli karena kredibilitas celebrity endorser tidak berpengaruh langsung secara langsung pada niat beli melainkan melalui daya tarik iklan dan efek iklan. Hal tersebut juga didukung oleh hasil studi Sertoglu et al. (2014) yang mengindikasikan bahwa juru bicara yang diciptakan memiliki kredibilitas yang lebih tinggi daripada celebrity endorser.

Penelitian Ruslim dan Andrew (2012), Wahyuni dan Suparna (2014), serta Wang dan Tsai (2014) diketahui bahwa kredibilitas seorang celebrity endorser memiliki pengaruh yang positif dan signifikan terhadap brand image, dan mempengaruhi purchase intention konsumen melalui brand image suatu produk. Berdasarkan pada fenomena dan hasil - hasil penelitian sebelumnya yang telah dipaparkan diatas, permasalahan dalam penelitian ini adalah untuk mengetahui berhasil atau tidaknya perusahaan Wardah dalam memanfaatkan kredibilitas 
celebrity endorser dan penciptaan brand image untuk menimbulkan niat beli pada konsumen, serta bagaimana peran brand image dalam memediasi kredibilitas celebrity endorser terhadap niat beli produk kosmetik Wardah di Kota Denpasar.

Berdasarkan sejumlah hasil penelitian terdahulu yang berbeda-beda atau adanya ketidakkonsistenan, maka penting melakukan pengujian kembali. Penelitian ini dilakukan pada kosmetik Wardah merujuk pada fenomena yang telah dipaparkan diatas dengan menguji hubungan-hubungan antar variabel kredibilitas celebrity endorser, brand image dan niat beli.

Tujuan penelitian dalam penelitian ini adalah untuk menjelaskan pengaruh kredibilitas celebrity endorser terhadap brand image pada produk kosmetik Wardah. Untuk menjelaskan pengaruh brand image terhadap niat beli produk kosmetik Wardah. Untuk menjelaskan pengaruh kredibilitas celebrity endorser terhadap niat beli produk kosmetik Wardah. Untuk menjelaskan peran brand image dalam memediasi pengaruh kredibilitas celebrity endorser terhadap niat beli produk kosmetik Wardah.

Celebrity endorser berperan sebagai orang yang berbicara tentang produk, yang dapat mempengaruhi sikap dan perilaku konsumen pada produk yang didukungnya (Kotler dan Keller, 2009:216). Menurut Arsinta dan Purnami (2015) kredibilitas celebrity endorser dapat diartikan sebagai kemampuan seorang celebrity endorser dalam memberikan informasi atau menyampaikan pesan dengan baik dan dapat dipercaya. Meskipun biaya kontrak celebrity endorser seringkali mencapai jutaan dolar, banyak perusahaan yang mempergunakan mereka, baik bintang film maupun atlet profesional dengan tujuan untuk 
mendukung dan meningkatkan penjualan produk mereka secara efektif (Chung et al. 2013). Kredibilitas dalam Kamus Besar Bahasa (KBBI) dapat diartikan sebagai perihal dapat dipercaya (kkbi.web.id). Kredibilitas celebrity endorser dapat diartikan sebagai kemampuan seseorang celebrity endorser dalam memberikan informasi pesan dengan baik agar mudah di tanggap oleh masyarakat.

Brand image menurut Kotler dan Keller (2009:403) adalah persepsi dan keyakinan yang dipegang oleh konsumen, seperti yang dicerminkan asosiasi yang tertanam dalam ingatan konsumen. Brand image yaitu suatu kumpulan asosiasi merek yang didasari oleh berbagai ketertarikan yang dikembangkan oleh konsumen pada setiap waktu, brand seperti manusia dapat berupa gagasan yang mempunyai masing-masing personality (Shimp, 2007:38).

Suryani (2008:113) mendefinisikan citra merek ialah keseluruhan persepsi konsumen terhadap merek yang terbentuk karena informasi dan pengalaman konsumen terhadap suatu merek. Maka dapat disimpulkan citra merek adalah proses seseorang dalam mengartikan persepsi terhadap suatu merek yang terbentuk karena informasi dan pengalaman konsumen terhadap suatu merek (Wijanarko et al. 2016)

Niat beli adalah perilaku konsumen yang muncul sebagai respon terhadap objek yang menunjukkan keinginan pelanggan untuk melakukan pembelian Kotler dan Keller (2009:137). Niat beli dapat diartikan sebagai keinginan untukmembeli di mana menurut Peter dan Olson (2007:149) keinginan adalah sebuah rencana untuk terlibat dalam suatu perilaku khusus guna mencapai tujuan. 
Perilaku (behavioral) adalah tindakan khusus yang ditujukan pada beberapa objek target.

Menurut Randi dan Heryanton (2016) Minat dalam pembelian menicptakan sutu motivasi yang terus terekam dalam benak konsumen dan menjadi suatu keinginan yang sangat kuat yang pada akhirnya ketika seseorang konsumen harus memenuhi kebutuhannya, maka mereka akan mengaktualisasikan apa yang ada didalam benaknya.

Maulana dalam Amanda (2014) menyatakan bahwa terdapat pengaruh antara kredibilitas celebrity endorser dengan brand image, yaitu penggunaan celebrity endorser lebih efektif menghasilkan respon yang positif terhadap brand image, sekaligus meningkatkan keinginan untuk membeli.

Hasil penelitian Rini dan Astuti (2012), Nisa dan Amal (2013) serta Sari dan Djatikusuma (2013) kredibilitas seorang celebrity endorser berpengaruh signifikan dan positif terhadap brand image karena penggunaan celebrity endorser yang tepat dapat meningkatkan brand image suatu produk atau layanan dan dapat meningkatkan niat beli.

$\mathrm{H}_{1}$ : Kredibilitas celebrity endorser berpengaruh positif dan signifikan terhadap brand image.

Rahma dalam Kurniawan (2012) mengemukakan bahwa brand image akan berpengaruh langsung terhadap tingginya minat beli terhadap suatu produk karena konsumen akan memiliki alasan untuk membeli atau menggunakan produk dengan brand image yang dianggap khalayak sebagai produk yang baik, berkualitas, dan dipakai oleh orang terkenal. 
Berdasarkan penelitian dari Ruslim dan Andrew (2012), Jalilvand dan Samei (2012), Wahyuni dan Suparna (2014), Wang dan Tsai (2014), serta Subiyanto (2013) didapatkan hasil bahwa terdapat pengaruh yang positif dan signifikan antara brand image dan purchase intention.

$\mathrm{H}_{2}$ : Brand image berpengaruh positif dan signifikan terhadap niat beli.

Shafiq et al. (2011) menyatakan bahwa celebrity endorser merupakan sosok orang yang menarik, mampu mengiklankan produk, dan memiliki kredibilitas yang baik, sehingga dapat menumbuhkan niat beli pada orang yang melihat iklan dan untuk membeli produk yang diiklankan. Putra dan Giantari (2014) menyatakan, semakin baik dan gencar perusahaan dalam melakukan penjualan dengan menggunakan celebrity endorser, maka niat membeli sepeda motor automatic merek Honda akan mengalami peningkatan.

Hasil penelitian Sallam (2011) menunjukkan hasil bahwa kredibilitas celebrity endorser memiliki pengaruh yang positif pada niat beli konsumen di Arab Saudi. Temuan yang sama ditunjukkan pada studi yang dilakukan oleh Hansudoh (2012), Indraswari dan Pramudana (2014), Zafar (2012), Apejoye (2013) serta Khan (2013) juga menunjukkan bahwa kredibilitas celebrity endorser mempengaruhi niat beli konsumen.

Bertentangan dengan hasil-hasil studi sebelumnya, temuan penelitian yang dilakukan oleh Stephanie dkk. (2013) menggambarkan bahwa kredibilitas celebrity endorser tidak berpengaruh secara langsung pada niat beli melainkan melalui daya tarik iklan (advertising appeal) dan efek iklan (advertising effect). Hal tersebut juga didukung oleh hasil studi Sertoglu et al. (2014) yang 
mengindikasikan bahwa juru bicara yang diciptakan (created spokesperson) memiliki kredibilitas yang lebih tinggi daripada celebrity endorser

$\mathrm{H}_{3}$ : Kredibilitas celebrity endorser berpengaruh positif dan signifikan terhadap niat beli.

Rini dan Astuti (2012) menyatakan bahwa kredibilitas celebrity endorser berpengaruh secara positif dan signifikan terhadap brand image. Suatu produk yang memiliki brand image yang baik merupakan salah satu cara yang efektif di dalam menjaring konsumen, karena konsumen dengan sadar atau tidak sadar akan memilih suatu produk yang memiliki brand image yang positif, sehingga tercipta persepsi yang baik di mata konsumen, dan akan mempengaruhi konsumen dalam proses keputusan pembelian yang pada akhirnya menciptakan loyalitas terhadap suatu merek produk tertentu.

Berdasarkan hasil penelitian Ruslim dan Andrew (2012), Wahyuni dan Suparna (2014), serta Wang dan Tsai (2014) diketahui bahwa kredibilitas seorang celebrity endorser memiliki pengaruh yang positif dan signifikan terhadap brand image, dan mempengaruhi purchase intention konsumen melalui brand image suatu produk.

$\mathrm{H}_{4}$ : Brand image memediasi pengaruh kredibilitas celebrity endorser terhadap niat beli.

\section{METODE PENELITIAN}

Penelitian ini dilakukan di Kota Denpasar. Kota Denpasar merupakan wilayah dengan penduduk yang padat dan memiliki kesadaran yang tinggi akan kebutuhan perawatan wajah dan tubuh dengan kosmetik. Dengan begitu responden yang sesuai dengan kriteria akan mudah ditemui sehingga dapat memperoleh data yang komprehensif. 
Tabel 2.

Indikator Variabel Penelitian

\begin{tabular}{|c|c|c|}
\hline Variabel & Indikator & Sumber \\
\hline $\begin{array}{l}\text { Kredibilitas Celebrity } \\
\text { Endorser }(\mathrm{X})\end{array}$ & $\begin{array}{l}\text { 1. Daya tarik (X.1) } \\
\text { 2. Dapat Dipercaya (X.2) } \\
\text { 3. Keahlian (X.3) }\end{array}$ & $\begin{array}{l}\text { Hansudoh (2012), } \\
\text { Stephani dkk. (2013) dan } \\
\text { Sertoglu et al. (2014) }\end{array}$ \\
\hline Brand Image (Y1) & $\begin{array}{l}\text { 1. Daya ingat konsumen akan merek } \\
\text { (Y1.1) } \\
\text { 2. Kualitas Produk (Y1.2) } \\
\text { 3. Citra produk (Y1.3) } \\
\text { 4. Keunikan (Y1.4) }\end{array}$ & $\begin{array}{l}\text { Schiffman dan Kanuk } \\
\text { (2006), Shimp (2014) } \\
\text { dan Hamdina (2015). }\end{array}$ \\
\hline Niat Beli (Y2) & $\begin{array}{l}\text { 1. Mencari informasi mengenai produk } \\
\text { (Y2.1) } \\
\text { 2. Keinginan untuk segera membeli } \\
\text { (Y2.2) } \\
\text { 3. Memiliki preferensi bahwa produk ini } \\
\text { yang dicari(Y2.3) }\end{array}$ & Tanomi (2012) \\
\hline
\end{tabular}

Populasi dalam penelitian ini adalah konsumen yang berdomisili di Kota Denpasar dan belum pernah melakukan pembelian produk kosmetik Wardah. Ukuran sampel memegang peranan penting dalam estimasi dan interpretasi hasil analisis. Ferdinand (2002: 47) mengemukakan bahwa ukuran sampel yang sesuai untuk suatu peneliatian adalah antara 100-200. Malhotra (2004: 291) menjelaskan cara untuk penentuan jumlah sampel yakni minimal 5-10 kali jumlah indikator dalam penelitian. Penelitian ini menggunakan 10 indikator yang berarti sampel yang diperlukan minimal $50(5 \times 10)$ dan maksimal 100 (10x10). Penelitian ini menggunakan 100 sampel.

Metode penentuan sampel yang digunakan pada penelitian ini adalah non probability sampling dengan metode purposive sampling, yaitu sampel ditentukan dengan pertimbangan tertentu (Sugiyono, 2016:96). Digunakan teknik non probability sampling karena jumlah konsumen yang tidak pernah melakukan 
pembelian pada produk kosmetik Wardah di Kota Denpasar tidak tersedia dengan jumlah yang pasti dan kemudian populasi akan berubah secara periodik yang tidak diketahui.

Metode pengumpulan data yang digunakan dalam penelitian ini yaitu menyebarkan kuesioner langsung kepada responden dengan jumlah sampel sebanyak 100 responden. Kuesioner diberikan secara konvensional dengan bertatap muka langsung dengan responden. Daftar pertanyaan yang diberikan kepada responden mengenai kredibilitas celebrity endorser, brand image dan niat beli pada kosmetik Wardah. Selanjutnya butir-butir pernyataan diukur dengan skala Likert.

Teknik analisis data yang digunakan dalam penelitian ini adalah teknik analisis jalur (path analysis). Teknik analisis jalur ini dapat didefinisikan sebagai perluasan dari analisis linier berganda dalam memperkirakan hubungan kausalitas antara yang telah ditetapkan berdasarkan teori. Analisis jalur digunakan untuk menentukan hubungan 3 variabel atau lebih dalam mengkorfimasi dan menolak hipotesis (Ghozali, 2011:249). Analisis jalur digunakan untuk menganalisis pola hubungan antar variabel dengan tujuan untuk mengetahui pengaruh langsung maupun tidak langsung variabel eksogen terhadap variabel endogen. Dasar perhitungan koefisian jalur adalah analisis korelasi dan regresi dan dalam perhitungannya menggunakan software dengan program SPSS for windows. (Riduwan dan Kuncoro, 2011:2). 


\section{HASIL PENELITIAN DAN PEMBAHASAN}

Karakteristik responden dalam penelitian ini ditinjau dari beberapa variabel demografi yang digambarkan melalui variabel usia, pendidikan, dan pekerjaan. Karakteristik demografi responden ditunjukan pada tabel 3. berikut.

Tabel 3.

Karakteristik Responden

\begin{tabular}{clcc}
\hline Variabel & \multicolumn{1}{c}{ Klasifikasi } & Jumlah (orang) & Presentase (\%) \\
\hline \multirow{5}{*}{ Usia (Tahun) } & $18-23$ & 69 & 69 \\
& $23-30$ & 12 & 12 \\
& $30-37$ & 10 & 10 \\
& $37-44$ & 8 & 8 \\
& $>44$ & 1 & 1 \\
& Jumlah & $\mathbf{1 0 0}$ & $\mathbf{1 0 0}$ \\
& SMA/SMK & 65 & 65 \\
& Diploma & 12 & 12 \\
& S1 & 23 & 23 \\
& Lainnya & 0 & 0 \\
& Jumlah & $\mathbf{1 0 0}$ & $\mathbf{1 0 0}$ \\
& Pelajar/Mahasiswa & 65 & 65 \\
& Pegawai Negeri Sipil & 6 & 17 \\
& Pegawai Swasta & 17 & 8 \\
& Wiraswasta & 8 & 4 \\
& Lainnya & 4 & $\mathbf{1 0 0}$ \\
\hline
\end{tabular}

Sumber: Data diolah, 2017

Tabel 3 menunjukan jika ditinjau dari kiteria usia, responden dengan rentang umur 18-23 tahun mendominasi sebaran kuesioner ini yaitu sebesar 69 persen yang menunjukan mayoritas responden berada pada jenjang usia produktif atau sedang bekerja maupun sedang menempuh pendidikan di perguruan tinggi. Responden dengan rentang umur 23-30 adalah sebesar 12 persen, rentang umur lebih dari 30-37 tahun sebesar 10 persen, rentang umur lebih dari 37-44 adalah sebesar 8 persen, serta responden yang usianya lebih dari 44 tahun sebesar 1 persen.

Ditinjau dari kiteria pendidikan, responden rata-rata memiliki tamatan SMA/SMK yang mendominasi sebaran kuesioner sebesar 65 persen yang 
menunjukan mayoritas responden tamatan SMA/SMK sehingga mampu memilih kosmetik yang sesuai dengan jenis kulitnya. Responden dengan tamatan pendidikan Diploma adalah sebesar 12 persen, tamatan pendidikan S1 adalah sebesar 23 pesen, responden lainnya atau tamatan yang lebih tinggi yaitu sebesar 0 persen.

Ditinjau dari kiteria pekerjaan, responden dengan pekerjaan pelajar/mahasiswa mendominasi sebaran kuesioner yaitu sebesar 65 persen yang menunjukan mayoritas responden cenderung gemar menggunakan berbagai macam kosmetik yang aman bagi kesehatan kulitnya, mengandung bahan yang yang halal sehingga cocok untuk kulit yang rat-rata masih dalam tahap pertumbuhan dengan menggunakan kosmetik Wardah. Responden dengan pekerjaan pegawai negeri sipil adalah sebesar 6 persen, sebesar 17 persen adalah pegawai swasta, sebesar 8 persen adalah pegawai wiraswasta, dan pekerjaan lainya seperti ibu rumah tangga adalah sebesar 4 persen.

Pengujian persamaan 1 dilakukan untuk melihat pengaruh kredibilitas celebrity endorser terhadap brand image yang dilakukan dengan menggunakan program SPSS. Berdasarkan hasil olah data, maka dapat disajikan dalam persamaan regresi sebagai berikut:

$$
\begin{aligned}
& \dot{Y}=5,955+0,801 \mathrm{X} \\
& \mathrm{S}(\beta)=(1.048) \quad(0,088) \\
& \mathrm{t} \quad=(5.677) \quad(9,148) \\
& \text { Sig }=(0,000) \quad(0,000) \\
& \mathrm{R}^{2}=0,461 \quad \mathrm{df}=98 \quad \mathrm{~F}=83.686 \quad \mathrm{Sig}=0,000
\end{aligned}
$$

Hasil olah data diatas menunjukan hasil uji regresi persamaan 1 pengaruh kredibilitas celebrity endorser terhadap brand image dengan nilai Sig. 0,000 < 
0,05 menunjukkan bahwa kredibilitas celebrity endorser berpengaruh positif dan signifikan berhadap terhadap brand image.

Pengujian persamaan 2 dilakukan untuk melihat pengaruh kredibilitas celebrity endorser dan brand image terhadap niat beli yang dilakukan dengan menggunakan program SPSS. Berdasarkan hasil olah data pada lampiran 6, maka hasil uji regresi dapat disajikan sebagai berikut:

$$
\begin{array}{lrrrr}
\hat{Y} & =3,325 & +0,303 \mathrm{X} & +0,375 \mathrm{Y}_{1} & \\
\mathrm{~S}(\beta)=(0,904) & (0,089) & (0,375) & \\
\mathrm{t} & =(3,678) & (3.397) & (4,961) & \\
\mathrm{Sig}= & (0,000) & (0,001) & (0,000) & \\
\mathrm{R}^{2}=0,530 & \text { df }=97 & \mathrm{~F}=54,727 & \text { Sig }=0,000
\end{array}
$$

Hasil uji regresi diatas menunjukan pengaruh kredibilitas celebrity endorser dan brand image terhadap niat beli. Kredibilitas celebrity endorser dengan nilai Sig. 0,001 < 0,05 menunjukkan bahwa kredibilitas celebrity endorser berpengaruh positif dan signifikan terhadap niat beli. Brand image dengan nilai Sig. $0,000<0,05$ menunjukkan bahwa brand image berpengaruh positif dan signifikan terhadap niat beli.

Berdasarkan hasil olah data diatas yang ditunjukan pada lampiran 6, maka dapat dibuat hubungan-hubungan antar variabel penelitian yang merupakan koefisien jalur dalam penelitian ini. Koefisien jalur dapat dibuat dalam bentuk diagram jalur. Model tersebut juga dapat dinyatakan dalam persamaan struktural, yaitu :

\section{Persamaan Struktural 1}

$\mathrm{Y}_{1}=0,679 \beta_{1} \mathrm{X}$ 
$\mathrm{Y}_{2}=0,470 \beta_{2} \mathrm{X}+0,322 \beta_{3} \mathrm{Y}_{1}$

\section{Persamaan Struktural 2}

Untuk mengetahui nilai $\mathrm{e}_{1}$ yang menunjukkan jumlah variance variabel brand image yang tidak dijelaskan oleh variabel kredibilitas celebrity endorser dihitung menggunakan rumus.

$\mathrm{e}_{\mathrm{i}}=\sqrt{1-R^{2}}$

$=\sqrt{1-0,641}$

$=0,734$

Nilai variance variabel brand image yang tidak dijelaskan oleh variabel kredibilitas celebrity endorser sebesar 0,734 berarti terdapat kumpulan variabel eksogen lainnya yang tidak dimasukkan dalam sistem penelitian yang dimungkinkan masih mempengaruhi variabel endogen atau niat beli $\left(\mathrm{Y}_{2}\right)$.

Sedangkan untuk mengetahui nilai $\mathrm{e}_{2}$ yang menunjukkan variance variabel niat beli yang tidak dijelaskan oleh variabel kredibilitas celebrity endorser dan brand image, maka dihitung menggunakan rumus.

$$
\begin{aligned}
\mathrm{e}_{2} & =\sqrt{1-R^{2}} \\
& =\sqrt{1-0,530} \\
& =0,685
\end{aligned}
$$

Nilai variance variabel niat beli yang tidak dijelaskan oleh variabel kredibilitas celebrity endorser dan brand image sebesar 0,685 berarti terdapat kumpulan variabel eksogen lainnya tidak dimasukkan dalam penelitian ini yang mungkin masih dapat mempengaruhi variabel endogen atau niat beli $\left(\mathrm{Y}_{2}\right)$.

Untuk memeriksa validitas model, terdapat indikator untuk melakukan pemeriksaan, yaitu koefisien determinasi total hasilnya sebagai berikut. 
$\mathrm{R}_{\mathrm{m}}^{2}=1-\left(\mathrm{Pe}_{1}\right)^{2}\left(\mathrm{Pe}_{2}\right)^{2}$

$\mathrm{R}_{\mathrm{m}}^{2}=1-(0,734)^{2}(0,685)^{2}$

$\mathrm{R}_{\mathrm{m}}^{2}=0,748$

Keterangan :

$\mathrm{R}^{2}{ }_{\mathrm{m}} \quad$ : Koefisien determinasi total

$\mathrm{e}_{1}, \mathrm{e}_{2}$ : Nilai kekeliruan taksiran standar

Berdasarkan hasil perhitungan koefisien determinasi total, maka diperoleh bahwa keragaman data yang dapat dijelaskan oleh model adalah sebesar 74,8 persen atau dengan kata lain informasi yang terkandung dalam data sebesar 74,8 persen dapat dijelaskan oleh model sedangkan sisanya 25,2 persen dijelaskan oleh variabel lain yang tidak terdapat dalam model.

Uji mediasi variabel brand image $\left(\mathrm{Y}_{1}\right)$ atas hubungan kredibilitas celebrity endorser $(\mathrm{X})$ terhadap niat beli $\left(\mathrm{Y}_{2}\right)$. Uji Sobel dirumuskan dengan persamaan berikut:

$$
\begin{aligned}
& \mathrm{a}=0,679 \\
& \mathrm{~b}=0,470 \\
& \mathrm{~S}_{\mathrm{a}}=0,088 \\
& \mathrm{~S}_{\mathrm{b}}=0,076 \\
& \mathrm{~S}_{\mathrm{ab}}=\sqrt{\mathrm{b}^{2} \mathrm{~S}_{\mathrm{a}}{ }^{2}+\mathrm{a}^{2} \mathrm{Sb}^{2}+\mathrm{S}_{\mathrm{a}}{ }^{2} \mathrm{Sb}^{2}} \\
& =\sqrt{(0,470)^{2}(0,088)^{2}+(0,679)^{2}(0,076)^{2}+(0,088)^{2}(0,076)^{2}} \\
& =0,066471 \\
& \mathrm{t}=\frac{a}{\mathrm{~S}_{\mathrm{a}}}=\frac{(0,6)(0,4)}{0,0}=\frac{0,3}{0,0}=4,8011 \\
& \mathrm{t} \text { hitung }=4,8011 \\
& \text { t tabel (df: 97, a: 0,05) =1,9847 } \\
& \mathrm{t} \text { hitung }>\mathrm{t} \text { tabel }=4,8011>1,9847
\end{aligned}
$$

Keterangan :

$\mathrm{S}_{\mathrm{ab}}=$ besarnya standard error tidak langsung

$\mathrm{S}_{\mathrm{a}} \quad=$ standard error koefisien a

$\mathrm{S}_{\mathrm{b}} \quad=$ standard error koefisien $\mathrm{b}$

$\mathrm{a} \quad=$ koefisien jalur $\mathrm{X}$ terhadap $\mathrm{Y}_{1}$ 
$\mathrm{b} \quad=$ koefisien jalur $\mathrm{Y}_{1}$ terhadap $\mathrm{Y}_{2}$

$\mathrm{ab}=$ hasil kali koefisien jalur $\mathrm{X}$ terhadap koefisien jalur $\mathrm{Y}_{1}$ (a) dengan jalur $\mathrm{Y}_{1}$ terhadap $\mathrm{Y}_{2}(\mathrm{~b})$.

Pengaruh kredibilitas celebrity endorser terhadap brand image dalam penelitian ini di peroleh nilai koefisien beta sebesar 0,679 dengan tingkat signifikasi $0,000<0,05$, sehingga $\mathrm{H}_{0}$ ditolak dan $\mathrm{H}_{1}$ diterima, yang mengindikasi bahwa kredibilitas celebrity endorser berpengaruh positif dan signifikan terhadap brand image. Hasil tersebut mnunjukan bahwa semakin pelanggan mengingat suatu merek dengan melihat keahlian dan daya tarik celebrity endorser dalam penyapaian pesan maka akan meningkatkan brand image pada kosmetik Wardah.

Hasil rangkuman penilaian responden yang disajikan dalam deskripsi variabel penelitian menunjukan bahwa penilaian responden terhadap variabel kredibilitas celebrity endorser berada dalam katagori baik, sehingga menghasilkan variabel brand image berada dalam katagori baik. Responden menginat suatu merek yang di iklankan oleh selebriti dalam penyampaian informasi mengenai produk kosmetik Wardah.

Hasil penelitian ini diperkuat oleh penelitian sebelumnya yang dilakukan oleh Nisa dan Amal (2013), Sari dan Djatikusuma (2013) serta Rini dan Astuti (2012) yang menyatakan bahwa kredibilitas celebrity endorser berpengaruh positif dan signifikan terhadap brand image.

Pengaruh brand image terhadap niat beli dalam penelitian ini di peroleh nilai koefisien beta sebesar 0,470 dengan tingkat signifikasi $0,000<0,05$, sehingga $\mathrm{H}_{0}$ ditolak dan $\mathrm{H}_{1}$ diterima, yang mengindikasi bahwa brand image berpengaruh positif dan signifikan terhadap niat beli. Hasil tersebut menunjukan 
bahwa semakin pelanggan mengingat suatu merek maka akan semakin tinggi niat untuk membeli pada kosmetik Wardah.

Hasil rangkuman penilaian responden yang disajikan dalam deskripsi variabel penelitian menunjukan bahwa penilaian responden terhadap variabel brand image berada dalam katagori baik, sehingga menghasilkan variabel niat beli berada dalam katagori sangat baik. Responden memiliki niat beli tinggi pada kosmetik Wardah karena citra merek produk tersebut sesuai dengan yang dicari.

Hasil penelitian ini diperkuat oleh penelitian sebelumnya yang dilakukan oleh Ruslim dan Andrew (2012), Jalilvand dan Samei (2012), Wahyuni dan Suparna (2014), Wang dan Tsai (2014), serta Subiyanto (2013) yang menyatakan bahwa brand image berpengaruh positif dan signifikan terhadap niat beli.

Pengaruh kredibilitas celebrity endorser terhadap niat beli dalam penelitian ini di peroleh nilai koefisien beta sebesar 0,322 dengan tingkat signifikasi $0,001<$ 0,05, sehingga $\mathrm{H}_{0}$ ditolak dan $\mathrm{H}_{1}$ diterima, yang mengindikasi bahwa kredibilitas celebrity endorser berpengaruh positif dan signifikan terhadap niat beli. Hasil tersebut menunjukan bahwa semakin tertarik pelanggan dengan keahlian dari celebrity endorser makan akan semakin tinggi niat beli dari pelanggan pada kosmetik Wardah.

Hasil rangkuman penilaian responden yang disajikan dalam deskripsi variabel penelitian menunjukan bahwa penilaian responden terhadap variabel kredibilitas celebrity endorser berada dalam katagori baik, sehingga menghasilkan variabel niat beli berada dalam katagori sangat baik. Responden tertarik bahwa 
penyampaian informasi tetantang produk yang menimbulkan daya tarik dilakukan celebrity endorser akan menimbulkan niat beli pdan produk kosmetik Wardah.

Hasil penelitian ini diperkuat oleh penelitian sebelumnya yang dilakukan oleh Sallam (2011), Zafar (2012), Apejoye (2013) serta Khan (2013) yang menyatakan bahwa kredibilitas celebrity endorser berpengaruh positif dan signifikan terhadap niat beli.

Peran brand image dalam memediasi pengaruh kredibilitas celebrity endorser terhadap niat beli pada kosmetik Wardah telah diuji dalam penelitian ini. Hasil uji pengaruh kredibilitas celebrity endorser terhadap niat beli bernilai 0,322, kemudian pengaruh tidak langsungnya dengan adanya brand image di dalamnya menjadi sebesar 0,281 dengan pengaruh totalnya dari semua variabel menjadi sebesar 0,540. Hasil tersebut menunjukkan bahwa brand image memediasi pengaruh kredibilitas celebrity endorser terhadap niat beli. Uji Sobel yang telah dihitung memperkuat hasil tersebut dengan nilai koefisien $\mathrm{z}$ yang diperoleh adalah 4,801>1,98 dengan tingkat signifikansi $0,000<0,05$ sehingga $\mathrm{H}_{0}$ ditolak dan $\mathrm{H}_{1}$ diterima, yang mengindikasikan bahwa brand image dinilai mampu memediasi pengaruh kredibilitas celebrity endorser terhadap niat beli pada konsumen kosmetik Wardah.

Hasil penelitian ini didukung oleh penelitian sebelumnya yang dilakukan oleh Rini dan Astuti (2012), Ruslim dan Andrew (2012), Wahyuni dan Suparna (2014), serta Wang dan Tsai (2014) yang menyatakan bahwa brand image mampu memediasi pengaruh kredibilitas celebrity endorser terhadap niat beli. 
Implikasi dari hasil penelitian ini dibagi menjadi dua bagian, yaitu implikasi teoritis dan implikasi praktis. Implikasi teoritis adalah hal-hal yang perlu dilakukan peneliti berikutnya dalam rangka mengembangkan hasil penelitian ini, sedangkan implikasi praktis adalah hal-hal yang perlu diperhatikan terkait dengan pelaku bisnis khususnya pada koametik Wardah berkaitan dengan hasil penelitian. Pada penelitian ini, implikasi praktis dan teoritis dijelaskan secara rinci yaitu dalam rangka pengembangan teori tentang perilaku konsumen pada pembelian kosmetik khususnya kosmetik Wardah, bagi peneliti berikutnya diharapkan menambah indikator yang belum dimasukkan dalam variabel penelitian ini baik yang mempengaruhi citra merek maupun yang mempengaruhi kredibilitas selebriti pada niat beli kosmestik, ukuran sampel sebaiknya ditingkatkan sehingga hasilnya bisa lebih representatif.

Berdasarkan data responden yang secara langsung adalah pelaku yang belum pernah melakukan pembelin kosmetik wardah dapat dilihat bahwa semua variabel yaitu kredibilitas celebrity endorser memiliki pengaruh positif dan signifikan terhadap brand image, brand image memiliki pengaruh positif dan signifikan terhadap niat beli, kredibilitas celebrity endorser memiliki pengaruh positif dan signifikan terhadap niat beli, dan brand image memediasi pengaruh kredibilitas celebrity endorser terhadap niat beli . Dengan demikian pelaku bisnis dapat memperhatikan informasi guna mempertahankan citra merek dan dapat meningkatkan daya tarik pelanggan unuk melakukan pembelian. Penyampaian informasi dari selebriti lebih menarik sehingga pelanggan mudah untuk mengingat 
suatu merek sehingga akan menimbulkan niat beli karena banyaknya perusahaan yang akan berlomba-lomba menjadi pesaing dalam kebutuhan konsumen.

Patut disadari bahwa terdapat beberapa keterbatasan dalam penelitian ini, yaitu waktu yang cukup singkat dalam melakukan penelitian ini, sedangkan lingkungan, tren dan kebiasaan dapat berubah setiap saat, sehingga penelitian ini penting untuk dilakukan kembali. Ruang lingkup penelitian ini terbatas pada wilayah Kota Denpasar, sehingga hasil penelitian ini tidak dapat digeneralisasi untuk konsumen di luar wilayah Kota Denpasar.

\section{SIMPULAN DAN SARAN}

Simpulan yang dapat diberikan berdasarkan pembahasan hasil penelitian yang telah dilakukan, yaitu kredibilitas celebrity endorser berpengaruh positif dan signifikan terhadap brand image. Hasil penelitian menunjukan bahwa semakin pelanggan mengingat suatu merek dengan melihat keahlian dan daya tarik celebrity endorser dalam penyapaian pesan maka akan meningkatkan brand image pada konsumen kosmetik Wardah di Kota Denpasar.

Brand image berpengaruh positif dan signifikan terhadap niat beli. Hasil penelitian menunjukan bahwa semakin pelanggan mengingat suatu merek maka akan semakin tinggi niat untuk membeli pada konsumen kosmetik Wardah di Kota Denpasar.

Kredibilitas celebrity endorser berpengaruh positif dan signifikan terhadap niat beli. Hasil penelitian menunjukan bahwa semakin tertarik pelanggan dengan keahlian dari celebrity endorser maka akan semakin tinggi niat beli dari pelanggan pada kosmetik Wardah di Kota Denpasar. 
Brand image memediasi pengaruh kredibilitas celebrity endorser terhadap niat beli. Hasil penelitian ini menunjukan bahwa kekuatan brand image dapat mempengaruhi dan mementukan pengaruh kredibilitas celebrity endorser terhadap niat beli pada konsumen kosmetik Wardah di Kota Denpasar.

Saran yang dapat diberikan berdasarkan kesimpulan yang didapat adalah tanggapan responden pada variabel kredibilitas celebrity endorser memperlihatkan indikator selebriti dapat dipercaya dalam menyampaikan informasi merupakan variabel yang memperoleh skor terendah, maka sebaiknya pihak produsen kosmetik Wardah mampu memilih seorang endorser yang dapat menyampaikan iklan yang baik, sehingga akan meningkatkan minat calon konsumen untuk membeli produk kosmetik Wardah.

Tanggapan responden pada variabel brand image memperlihatkan indikator produk kosmetik Wardah yang dibintangi celebrity endorser lebih unggul dari produk sejenisnya merupakan variabel yang memperoleh skor terendah, maka sebaiknya pihak produsen wardah memilih celebrity yang sesuai dengan produk yang di iklankan yang akan menonjolkan suatu merekdan kualitas dari produk kosmetik Wardah sehingga akan terlihat lebih unggul dari produk lainnya.

Tanggapan responden pada variabel niat beli memperlihatkan indikator tertarik untuk mencoba produk kosmetik Wardah merupakan variabel yang memperoleh skor terendah, maka sebaiknya pihak produsen kosmetik Wardah lebih memberikan inovasi yang lebih menarik sehingga konsumen akan penasaran dengan produk kosmetik Wardah yang akan menimbulkan niat beli dan meningkatkan upaya promosi. 
Bagi peneliti selanjutnya, dihaapkan dapat menambah variabel yang berpengaruh terhadap citra merek dan niat beli. Selain itu dengan melibatkan responden yang lebih banyak akan meghasilkan data yang lebih akurat.

\section{REFERENSI}

Amanda, Putri. 2014. Peran Brand Image dalam Memediasi Hubungan Celebrity Endorser dengan Brand Equity Kartu Halo. Jurnal Ilmiah Mahasiswa Universitas Widyatama, h: 53-67.

Apejoye, Adeyanju. 2014. Influence Of Celebrity Endorsement Of Advertisement On Students Purchase Intention. Mass Communication And Journalism. Journal of Management, 3(3): pp. 1-7.

Bhakar, S. S., S. Bhakar, S. Bhakar. 2013."Relationship Between Country of origin, Brandimage and Customer Purchase intentions"Far East Journal of Psychology and Business , 10 (2), pp: 25-47.

Chung, Y.C., Kevin., Derdenger, T.P., and Kannan.S. 2013. Economic value of celebrity endorsement: Tiger Woods' impact on sales of Nike Golf Balls. Marketing Science, 32 (2), pp: 271-293.

Ferdinand, Augusty. 2002. Structural Equation Modeling dalam Penelitian Manajemen. Semarang: Badan Penerbit Universitas Diponegoro.

Ghozali, I. 2011. Aplikasi Analisis Multivariate dengan Program SPSS. (Trans: Application of Multivariate Analysis using SPSS). Badan Penerbit UNDIP, ISBN 979.704.300.2. Semarang.

Hansudoh, Steven Agustisnus. 2012. Pengaruh Celebrity Endorsement Terhadap Purchase Intention Melalui Perceived Value Pada Produk Top Coffe di Surabaya. E-Journal Universitas Katolik Widya Mandala Surabaya, 1 (05), h: 1-7.

Indraswari, M., Mahadewi, N.M., dan Pramudana, K.A.S. 2014. Pengaruh kredibilitas celebrity endorser dan kewajaran harga terhadap niat beli konsumen wanita pada Online Shop produk pakaian. E-Journal Manajemen Universitas Udayana, 3 (4), h: 938-955.

Jalilvand, Mohammad Reza, Neda Samiei. 2012. The Effect of Electronic Word of Mouth on Brand Image and Purchase Intention. Marketing Intelligence \& Planning, 30 (4), pp: 460-476.

Khan, Bilal M. 2013. The Effect of Indian Celebrity Credibility Dimensions on Purchase Intention of Indian Consumers. Published in Prague Conference, IISES and University of Economics Prague.

Kurniawan, Saverius Dwi. 2012. Analisis Pengaruh Brand Loyalty, Brand Image, Iklan dan Percieved Quality Terhadap Niat Beli Konsumen XL Prabayar 
di Kota Surabaya. Jurnal Universitas Katolik Widya Mandala Surabaya, 1 (1), h: 1-5.

Kotler, P., dan Keller, K.L. 2009. Manajemen Pemasaran, Edisi Ketiga Belas Jilid 1. Jakarta: Erlangga

Malhotra, Naresh K. 2004. Riset Pemasaran: Pendekatan Terapan, Jilid I. Jakarta: Indeks.

Nisa, Lathifatun Hanif dan Nora Nailul Amal. 2013. Celebrity Endorser dan Brand Image (Studi Kuantitatif Eksplanasi Pengaruh Sule Sebagai Celebrity Endorser Dalam Iklan Televisi Terhadap Pembentukan Brand Image Kartu AS Telkomsel Di Kalangan Mahsiswa Komunikasi FISIP UNS Angkatan 2011/2012). Jurnal Ilmiah Ilmu Komunikasi Fakultas Ilmu Sosial dan Ilmu Politik. h: 1-17.

Pangastuti A, Gst.A., Purnami N.Md. Peran Persepsi Nilai dalam memediasi pengaruh kredibilitas celebrity endorser ada niat beli produk kosmetik maybelline di kota denpasar. Universitas Udayana. Jurnal Manajemen, Strategi Bisnis dan Kewirausahaan. 9 (2), h: 123-134

Peter, J Paul and Jerry C Olson. 2013. Perilaku Konsumen dan Strategi Pemasaran Terjemahan oleh Diah Tantri Dwiandani Edisi Kesembilan Jilid 1. Jakarta: Erlangga.

Pradhan Debasis, Israel Duraipadian., and Dhruv Sethi. 2014. Celebrity Endorsement: How Celebrity- Brand - User Personality Congruence Affects Brand Attitude And Purchase Intention. Journal of Marketing Communications, 2(2): pp. 1-18.

Prayuana, Helena Hermawati, Anik Lestari Andjarwati.2013.Pengaruh Penggunaan Celebrity Endorser Irfan Bachdim dan Event Sponshorship terhadap Citra Merek Minuman Isotonik Pocari Sweat. Jurnal Ilmu Manajemen, 1(1).

Putra, I M.S.M dan Giantari, I. G.A.K. 2014. Pengaruh brand image, celebrity endorser, kualitas produk, dan kewajaran harga terhadap niat membeli Sepeda Motor Matic Merek Honda di Kota Denpasar. E-Journal Manajemen Universitas Udayana, 3 (10), h: 2869-2886.

Putra, Triya Darma I.K dan Eka Sulistyawati, 2015. Peran Brand Image dalam Memediasi Pengaruh Celebrity Endorser Terhadap Niat Beli. E-Jurnal Manajemen Universitas Udayana. 4(6), hal 1722-1734

Randi. Heryanto, Meyzi. 2016. Pengaruh Citra Merek Terhadap Minat Beli Pada Makanan Fast Food Ayam Goreng ( Studi pada Konsumenn Texas Chicken Pekanbaru). Jurnal Online Mahasiswa Fakultas Ilmu Sosial dan Ilmu Politik Universitas Riau. 3(2). h: 1-9

Riduwan dan Engkos Achmad Kuncoro. 2011.Cara Menggunakan dan Memaknai Analisis Jalur (Path Analysis). Bandung: Alfabeta. 
Rini, Endang Sulistya dan Dina Widya Astuti. 2012. Pengaruh Agnes Monica Sebagai Celebrity Endorser Terhadap Pembentukan Brand Image Honda Vario. Jurnal Bisnis dan Manajemen, 6 (6), h: 1-12.

Roy, S., V. Jain, and P. Rana. 2013. The Moderating Role of Consumer Personality and Source Credibility in Celebrity Endorsements. AsiaPacific Journal of Business Administration, 5(1), pp: 72-88

Ruslim, Tommy Setiawan dan Richard Andrew. 2012. Pengaruh Brand Image dan Product Knowledge Terhadap Purchase Intention (Kasus: Kosmetik Merek “X”). Jurnal Media Bisnis Universitas Tarumanegara, 4 (1), h: 34-44

Sallam, Methaq Ahmed Abdulmajid. 2011. The Impact of Source Credibility on Saudi Consumer's Attitude Toward Print Advertisement: The Moderating Role of Brand Familiarity. International Journal of Marketing Studies, 3 (4), pp: 63-77

Sabunwala, Z. 2013. Impact of Celebrity Brand Endorsements on Citra merekand Product Purchase - A Study for Pune Region of India. International Journal of Research in Business Management. 1(6), pp: 37-42.

Sari, Dinny Puspita dan Edin S. Djatikusuma. 2013. Pengaruh Celebrity Endorser Ayu Ting Ting Dalam Iklan Televisi Terhadap Brand Image Produk Mie Sarimi. STIE MDP, h: 1-9.

Shafiq, R., Raza, I., Rehman, M. Z. 2011. Analysis of The Factors Affecting Customers' Purchase Intention: The Mediating Role of Percieved Value. African Journal of Business Management, 5 (26), pp: 10577-10585

Schiffman, Leon G. dan Leslie Lazar Kanuk. 2008. Perilaku Konsumen, Edisi Ketujuh. Jakarta: PT Indeks.

Shimp, Terence A. 2003. Periklanan Promosi: Aspek Tambahan Komunikasi Pemasaran Terpadu. Alih bahasa oleh Revyani Sahrial dan Dyah Anikasari. Edisi Kelima Jilid 1. Jakarta: Erlangga

Stephanie, Elizabeth., dan Leonid Julihan Rumambi. 2013. Analisa Pengaruh Rio Dewanto Dan Donita Sebagai Celebrity Endorser Terhadap Minat Beli Produk Axe Anarchy Dengan Daya Tarik Iklan Dan Efek Iklan Sebagai Variabel Intervening. Jurnal Manajemen Pemasaran, 1(2): h: 1-9.

Sugiyono. 2016. Metode Penelitian Administratif Dilengkapi Dengan Metode $R \& D$. Bandung : Alfabeta.

Suryani, Tatik. 2008. Perilaku Konsumen; Implikasi pada Strategi Pemasaran. Yogyakarta: Graha Ilmu.

Tanomi, Romy Victor. 2012. Pengaruh Iklan Terhadap Niat Beli Konsumen Melalui Citra Merek dan Sikap Pada Minuman Isotonik Mizone di Surabaya. Jurnal Ilmiah Mahasiswa Manajemen Universitas Widya Mandala, 1 (6), h: 1-7 
Wahyuni, Ni Luh Gede dan Gede Suparna. 2014. Pengaruh Brand Image dan Product Knowledge Terhadap Purchase Intention Produk Tas Tiruan Di Kota Denpasar. E-Journal Universitas Udayana, 3 (4), h: 1022-1034.

Wang, Ya-Hui., Cing-Fen Tsai. 2014. The Relationship Between Brand Image and Purchase Intention: Evidence From Award Winning Mutual Funds. The International Journal of Business and Finance Research, 8 (2), pp: $27-40$

Wijanarko,Puthud. Suharyono dan Zainu Arifin. 2016. Pegngaruh celebrity endorser terhadap citra merek dan dampaknya pada keputusan pembelian (Survei kepada Pengunjung Warung Kopi Kriwul, Kelurahan Merjosari, Kecamatan Lowokwaru, Kota Malang yang Pernah Melihat Iklan dan Membeli TOP Coffee). Jurnal Administrasi Bisnis. 34 (1), h: 165-171

Weli, I Made dan I Ketut Rahyuda, 2016. Peran brand image dalam memediasi country of origin terhadap purchase intention. E-Jurnal Manajemen Universitas Udayana, Vol. 5, No. 3 , hal : 1690-1716

Zafar, Q., dan Rafique, M. 2012. Impact of Celebrity Advertisement on Customers' Brand Perception and Purchase Intention. Journal of Business and Management Sciences, 1 (11), pp. 53-67. 